\title{
The effect of the state of the banking system on national economic resilience
}

\author{
Magomed Tashtamirov* \\ Chechen State University, A. Sheripova Str., 32, 364024 Grozny, Russia
}

\begin{abstract}
Economic resilience is directly related to the level of development of the banking system within a single economic space. This article identifies the degree of influence of the main indicators of the state of the banking system on the values of the resilience of the national economy of Russia. A review of the main research results in this area is carried out and the similarity of the positions of various authors on the issue of direct influence between the dynamics of banks' development and economic growth trends is revealed. The dynamic and structural analysis reflecting the degree of integration of the banking system and the Russian economy is carried out. The main determinants of the banking system, which have a direct impact on the dynamics of the national economy, are identified and systematized. An econometric analysis is carried out in the form of a regression model describing the degree of connection and influence of the main banking indicators on the stability of the Russian economy in terms of GDP per capita. The results obtained reflect a high degree of connection between the dynamics of indicators of the state of the banking system and the level the national economic resilience.
\end{abstract}

\section{Introduction}

In recent decades, the problem of ensuring sustainability has become a priority development plan for most of the world's countries, which is exacerbated under globalization of economic relations, technological revolutions, growing instability, and strengthening of the environmental agenda. The main goal of life for humanity until 2030 is to achieve sustainable rates of development, which is enshrined in the official documents of the UN [1]. This should involve economic growth in interaction with social development and preservation of the environment. The specified vector of social activity can be achieved through the reliable functioning of the banking sector.

The operation of the banking system in all types of economies is a determining factor in the long-term sustainable and stable development of the national economy and all its branches. Forming an integral system of credit and financial organizations within the national economy, the banking sector organizes and maintains a mechanism for mobilizing, accumulating, distributing, and redistributing capital of subjects of economic relations.

Many well-known economists have studied the role and importance of the banking system in economic growth and economic resilience within the framework of individual

${ }^{*}$ Corresponding author: basxo@yandex.ru 
states and the world economy. J. Schumpeter in his scientific work "Theory of Economic Development" noted the positive impact of credit institutions on the changes in national income, which can be achieved through the redistribution of accumulated savings in the most priority areas of economic activity [2].

Many works of the second half of the XX century notes and proves the positive impact of the state of the banking system on the trends of economic growth within national economies [3; 4].

R. Levin and S. Zevros emphasize the importance of the effective activity of credit and financial institutions in ensuring economic development through the search for various determinants of such influence $[5 ; 6]$.

Global and technological changes in the world economy inevitably affect the degree of interconnection between the banking system and trends in the development of national economies. Thus, F. Allen and D. Gale, studying the nature of the functioning of financial markets and their influence on the rate of economic development, concluded that the banking system reduces its impact on the economy in the context of the emergence of new technologies and innovative products [7], as well as with financing newly established companies [8].

Structural and transformational processes in national banking systems also contribute to a change in the main indicators of the sustainability and stability of the economies of individual countries and regions. An empirical study of the impact of the state of the financial system on the level of economic development in 10 countries with emerging markets revealed that the main driver of economic growth in such countries was the inflow of foreign banking capital, the privatization of state credit and financial organizations and the implementation of banking reforms. The described processes have together led to a decrease in operating costs and the stimulation of corporate lending [9].

Russian researchers have also come to a consensus regarding the direct impact of the state of the banking system and the rates of economic growth of individual countries. G. Tasunian, assessing the current state of the banking system and predicting the indicators of its long-term development, concluded that only the banking system can become a catalyst for the growth of the Russian economy. It must meet the competitive demands of consumers, increase the scale of its activities, and strengthen its presence in the country's economy [10].

The banking system also plays a big part in changing the cycles of development of the national economy, which is empirically confirmed in the work of A. Rakviashvili. Having studied the approach of the Bank of Russia to monetary policy and assessing the activities of banks in lending to the economy, the author concluded that the Central Bank of Russia and the entire banking system is a key factor in the cyclical nature of the onset of crisis phenomena in the national economy [11].

Thus, a review of the literature on the research topic shows that the banking system has a priority impact on the course of economic development and the changes in the economic growth of the national economy. However, the approach to assessing the degree of influence of the main indicators of the banking sector on the level of resilience of the national economy on the example of Russia has been insufficiently studied.

Since the country's transition from a planned to a market economy, the banking system of Russia has been actively integrated into the structure of the created gross domestic product (Fig. 1). 


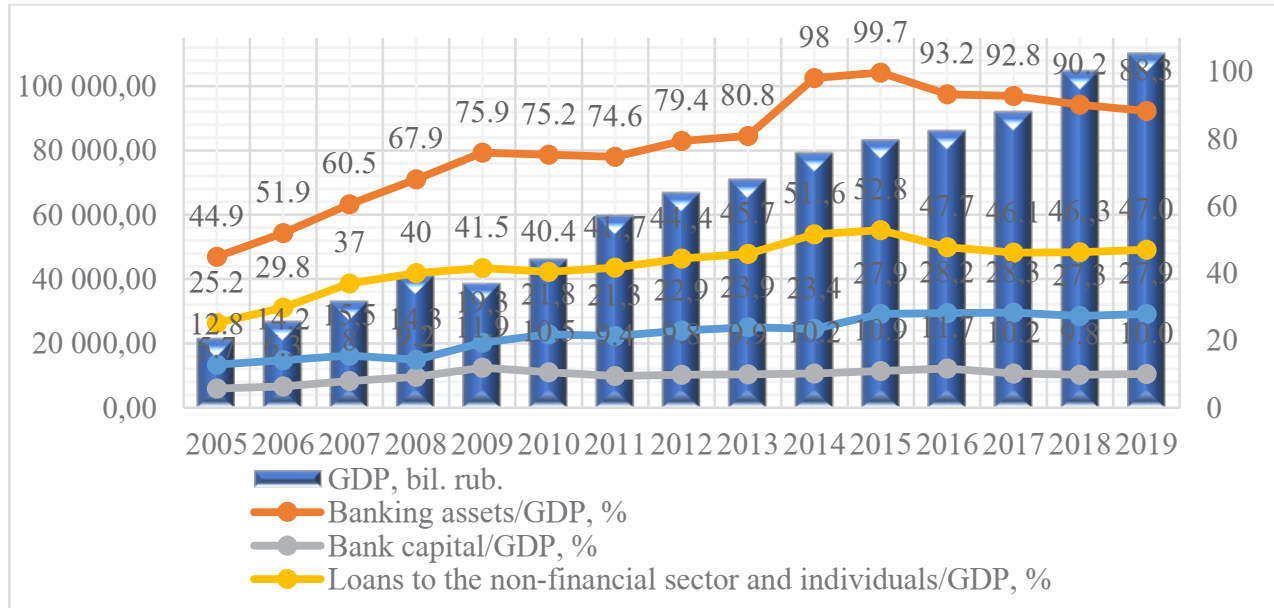

Fig. 1. Macroeconomic indicators of the Russian banking system for 2005-2019 [12]

The key indicators of the state of the banking system, such as the ratio of assets, loans, deposits to the country's GDP, characterize the growing banking presence in the Russian economy over the considered period. The peak was reached in 2015 (99.7\% of the share of assets in the country's economy), which was due to the crisis period of 2014-2016, accompanied by a decline in GDP after the collapse in the commodity and foreign exchange markets. However, the subsequent period since 2016 reflects the gap in the growth rates of the national economy and banking assets, as their share decreased to $88.3 \%$ as of the end of 2019.

Russia still lags behind the world average in the key indicators of the state and development of the banking sector relative to the national economy. The Russian values of lending to the private sector concerning GDP are almost twice lower than the world average. The share of arrears is also double the average levels for developed countries. The value of the ratio of banking assets to GDP in Russia is significantly lower than similar indicators in the group of developed countries but is at a relatively stable level in the group of developing economies [13].

Despite the insignificant indicators of integration of the banking system and the national economy of Russia, in comparison with developed countries and world average values, the degree of the banking sector's impact on the resilience of the Russian economy is quite tangible.

\section{Materials and Methods}

To study the degree of influence of the state of the banking system of Russia on its economic resilience, we should outline the main indicators of this relationship. Having reviewed the scientific literature on the method of analyzing the state of the banking system and forecasting its long-term development [14-16], it is necessary to identify and systematize the blocks of the main factors (see Table 1). 
Table. 1. Indicators of the state and development of the banking system

\begin{tabular}{|c|c|}
\hline Indicator & Calculation method \\
\hline \multicolumn{2}{|c|}{ Block I: institutional indicators } \\
\hline $\begin{array}{l}\text { Provision of the population with } \\
\text { banking institutions }\end{array}$ & $\begin{array}{c}\text { Number of internal structural divisions / } 100 \text { thousand } \\
\text { population }\end{array}$ \\
\hline $\begin{array}{l}\text { Provision of the population with } \\
\text { ATMs }\end{array}$ & Number of ATMs / 100 thousand population \\
\hline \multicolumn{2}{|c|}{ Block II: economic indicators } \\
\hline Change in assets & Growth rate of total banking assets \\
\hline Adequacy of bank capital & Total bank capital / total banking assets \\
\hline Loan portfolio quality & Share of overdue debt \\
\hline \multicolumn{2}{|c|}{ Block III: functional indicators } \\
\hline $\begin{array}{l}\text { Saturation of the economy with } \\
\text { banking assets }\end{array}$ & Total banking assets/country's GDP \\
\hline Capital saturation & Total bank capital/country’s GDP \\
\hline Credit saturation & Loans to the non-financial sector/country's GDP \\
\hline Deposit saturation & Individual's deposits/country's GDP \\
\hline
\end{tabular}

The indicators in Table 1 characterize various aspects of the functioning of the banking system in the national economy and determine the degree of influence on the changes in the economic growth of the state. On the other hand, the question remains as to what reflects the stability of the country's economy? Most scientific studies on the resilience of socioeconomic systems are based on the country's GDP in its absolute value (at current prices), the index of physical volume, concerning per capita. E. Gurvich and I. Prilepsky, in their study of the impact of external shocks on the stability of the Russian economy, took the current account balance, volumes of exports and imports, the exchange rate of the national currency, and the rate of GDP growth as the result values [17]. As the goal of this is to identify the internal factor impact on the stability of the economy, the indicators of the balance of payments and trade are not economically feasible.

Also, as an indicator of the national economic resilience, international organizations recommend the indicator of net adjusted (true) savings - the integrated ecologicalsocioeconomic index (adjusted net savings), which includes 8 components [18]. This indicator allows for a broader and more detailed consideration of the economy's ability to withstand the negative impact of internal determinants, after a three-stage correction together with the values of human capital and the environmental factor.

Accordingly, in terms of the interpretation of "resilience of the system" as the ability to withstand the negative impact of various endogenous and exogenous factors, while maintaining its internal structural and integral characteristics at an acceptable level, the following indicators of economic stability should be determined by the effective indicators of economic stability, as follows: GDP physical volume index; GDP per capita; the index of adjusted net savings to GDP.

To determine the degree of influence of the considered indicators on the level of resilience of the national economy, an econometric study was carried out through the construction of regression-correlation models. Dependent variables are indicators of the resilience of the national economy. Regressors are indicators of the state of the banking system from Table 1.

\section{Results and Discussion}

To determine the resulting factors, we will form 3 econometric models based on the variables and calculate the pairwise correlation to identify the greatest relationship. The observation period is $2007-2019$. 
Table. 2. Analysis of multiple correlations of indicators of the state of the banking system and the national economic resilience $[12,13,19]$

\begin{tabular}{|c|c|c|c|}
\hline Regressor & GDP, $\%$ & $\begin{array}{c}\text { GDP per capita, } \\
\text { rub. }\end{array}$ & $\begin{array}{c}\text { GDP adjusted net } \\
\text { savings index, } \%\end{array}$ \\
\hline $\begin{array}{c}\text { Provision of the population with } \\
\text { banking institutions }\end{array}$ & 0.132 & -0.726 & 0.114 \\
\hline $\begin{array}{c}\text { Provision of the population with } \\
\text { ATMs }\end{array}$ & -0.178 & 0.761 & -0.371 \\
\hline Change in assets & 0.479 & -0.455 & 0.525 \\
\hline Adequacy of bank capital & -0.114 & -0.819 & 0.015 \\
\hline Loan portfolio quality & -0.567 & 0.664 & -0.605 \\
\hline $\begin{array}{c}\text { Saturation of the economy with } \\
\text { banking assets }\end{array}$ & -0.489 & 0.815 & -0.584 \\
\hline Capital saturation & -0.863 & 0.239 & -0.887 \\
\hline Credit saturation & -0.460 & 0.759 & -0.506 \\
\hline Deposit saturation & -0.350 & 0.903 & -0.489 \\
\hline
\end{tabular}

The results of the correlation analysis in Table 2 reflect a high degree of correlation between indicators of the state of the banking system and the value of GDP per capita. A lower correlation can be traced with the GDP adjusted net savings index. The GDP physical volume index has the lowest correlation with the state of the banking system.

Based on the data obtained, we should note that GDP per capita is the most sensitive to changes in the state of the banking system. This correlation is especially traceable for the following factors:

- the ratio of deposits of individuals to the country's GDP has the highest direct impact on the GDP per capita;

- the ratio of bank capital to assets has the opposite effect on the changes in the resilience of the national economy in terms of GDP per capita;

- $\quad$ saturation of the economy with banking assets also has a direct impact on GDP per capita;

- the ratio of bank capital to the country's GDP has a high direct impact on the dynamics of GDP and net savings to the country's GDP;

- the quality of the loan portfolio has a moderate impact on all the considered indicators of economic stability;

- the provision of banking institutions and ATMs has a moderate direct and inverse impact, respectively, on the change in GDP per capita.

Based on the data of correlation analysis, we will construct a regression model for the GDP per capita indicator and factors with an average, moderate, and strong correlation

Table. 3. Results of the regression analysis of the influence of the banking system indicators on the level of economic resilience

\begin{tabular}{|c|c|c|c|c|c|c|c|}
\hline $\begin{array}{c}\text { GDP per } \\
\text { capita, rub. }\end{array}$ & $\begin{array}{c}\text { Deposit } \\
\text { saturation }\end{array}$ & $\begin{array}{c}\text { Adequacy } \\
\text { of bank } \\
\text { capital }\end{array}$ & $\begin{array}{c}\text { Saturation } \\
\text { of the } \\
\text { economy } \\
\text { with } \\
\text { banking } \\
\text { assets }\end{array}$ & $\begin{array}{c}\text { Provision } \\
\text { of the } \\
\text { population } \\
\text { with } \\
\text { ATMs }\end{array}$ & $\begin{array}{c}\text { Credit } \\
\text { saturation }\end{array}$ & $\begin{array}{c}\text { Provision } \\
\text { of the } \\
\text { population } \\
\text { with } \\
\text { banking } \\
\text { institutions }\end{array}$ & $\begin{array}{c}\text { Loan } \\
\text { portfol } \\
\text { io } \\
\text { quality }\end{array}$ \\
\hline $\mathrm{R}^{2}$ & 0.814 & 0.671 & 0.663 & 0.578 & 0.576 & 0.527 & 0.441 \\
\hline F-test & 0.00002 & 0.0006 & 0.0007 & 0.0025 & 0.0026 & 0.0049 & 0.0132 \\
\hline $\begin{array}{c}\text { Variable } \\
\text { coefficient }\end{array}$ & $32,095.4$ & $-90,235.1$ & $11,534.4$ & 3042.1 & $28,028.2$ & $-29,705.3$ & 75,218 \\
\hline Observations & \multicolumn{7}{|c|}{13} \\
\hline
\end{tabular}


The data in Table 3 indicate the high impact of 7 indicators of the state of the banking system on the national economic resilience in terms of GDP per capita, which is often used in cross-country analysis. All selected indicators have a statistical significance of $1 \%$, which indicates the correctness of the constructed econometric model.

If we use all 7 factors and build a multiple regression model for the dependent variable of GDP per capita, we get the following values:

$\mathrm{Y}=1,764,244.8635-38,781.148 \mathrm{X} 1-23,521.6715 \mathrm{X} 2-12,157.6452 \mathrm{X} 3+5,263.0051 \mathrm{X} 4+$ 23,025.7343X5 + 56,234.2882X6-39,020.8721X7; determination coefficient - 0.9917; Ftest is significant at 0.0057 .

The resulting equation can be used to predict the future level of resilience of the national economy, depending on changes in the selected effective factors.

\section{Conclusions}

The significant direct impact of the deposit saturation of the economy on its resilience carries a social aspect, as the propensity of the population to savings determines the growth of GDP value-added as an indicator of the growth of the well-being of citizens.

The growth of bank capital in the total volume of assets of the banking sector negatively affects the changes in GDP per capita, which is explained by the following thesis: the growth of the aggregate own bank capital concerning bank assets indicates a decrease in the role of banks in the economic development of the country, as the growing profit and capitalization of the banking sector is not a consequence of the growth of assets in the economy. In other words, banks profit from speculative operations without funding the real sector of the economy, which causes a disproportionate increase in bank capital relative to banking assets and the country's economy.

Despite the low indicators of the Russian banking system in the national economy compared to other countries, the share of banking assets in the national economy is a significant factor that has a direct impact on resilience.

During 2007-2019, the number of ATMs per 100 thousand people increased by 4 times, which led to a positive effect on the growth of the GDP per capita, as the development of the payment infrastructure accelerates the turnover of money capital in the economy and, consequently, economic development [20].

Changes in lending to the economy have a direct moderate impact on the level of stability of the national economy, which is a generally accepted factor for other countries. However, the Russian values of this influence differ from the world indicators due to the low integration of bank credit capital and the real sector of the country's economy.

Over the past 10 years, the reduction in the number of credit and financial organizations in Russia has gained pace, which is accompanied not only by the closure of banks but also the systematic closing of their regional branches and internal structural divisions of credit institutions [21]. This circumstance negatively affects the trend of national economic resilience as a result of a decrease in the level of provision of business entities with banking services.

Thus, the study of the Russian practice of the influence of the banking system on the resilience of the national economy confirmed the thesis of the close interaction of two aspects of state development. The banking sector, integrating into the system of financialeconomic and monetary-credit relations of economic agents of the state, actively influences the vector of short-term and long-term development. The ongoing transformation processes in the Russian banking system associated with its nationalization reduced institutional security, low participation in lending to the real sector of the economy, centralization and administrative concentration can become triggers for a decrease in the resilience and stability of the national economy. The national economy has not yet fully recovered from 
the crisis of 2014-2015, and again entered a new phase of recession in 2020 due to the coronavirus crisis and shocks in the commodity markets. This circumstance enhances the role of the banking sector in enhancing the economic security of the Russian economy and strengthening its stability.

Under the unstable indicators of the banking system and the national economy, the correctness and consistency of the chosen monetary policy by the Central Bank of Russia and the strategies of socio-economic and scientific-technological development of the country's economic management is of great importance.

\section{References}

1. Technical report by the Bureau of the United Nations Statistical Commission (UNSC) on the process of the development of an indicator framework for the goals and targets of the post-2015 development agenda (Working draft). Sustainable Development Knowledge Platform. United Nations, (2015)

2. J.A. Schumpeter, The Theory of Economic Development: An Inquiry into Profits, Capital, Credit, Interest and the Business Cycle (1982)

3. R. Goldsmith, Financial Structure and Development (1969)

4. E. Shaw, Financial Deepening in Economic Development (1973)

5. R. Levine, Handbook of Economic Growth,1, 865 (2005)

6. R. Levine, S. Zervos, The American Economic Review, 88, 537 (1998)

7. F. Allen, D. Gale, The Review of Financial Studies, 14, 577 (2001)

8. R. Rajan, L. Zingales, Banks and Markets: The Changing Character of European Finance, http://www.ecb.europa.eu/

9. G.M. Caporale, C. Rault, R. Sova, A. Sova, International Journal of Finance and Economics, 20, 48 (2015)

10. G. Tasunyan, Society and Economics, 9, 19 (2006)

11. A. Rakviashvili, Economic issues,6, 71 (2011)

12. Official Website of the Bank of Russia:Overview of the state of the banking sector. Statistics,http://cbr.ru/

13. Financial Sector. DataBank. TheWorldBankGroup, https://data.worldbank.org/

14. T.V. Pogodaeva, N.A. Baburina, E.P. Druz, M.P. Sheremetyeva, Finance and credit, 10, 2 (2016)

15. N.U. Abdunazarova, S.V. Chepel, Money and credit, 6, 45 (2016)

16. K. Teteryatnikov, Financial life, 2, 37 (2016)

17. E. Gurvich, I. Prilepsky, Economic issues, 9, 4 (2013)

18. Indicators of Sustainable Development: Guidelines and Methodologies. Third edition. United Nations. NewYork, (2007)

19. Federal State Statistics Service of the Russian Federation, https://rosstat.gov.ru/

20. M.R. Tashtamirov, National economic systems in the context of the formation of global economic space. Collection of scientific works: in 2 volumes (2019)

21. M.R. Tashtamirov, L.V. Mazaeva, Z.D. Kuriev, Bulletin of Eurasian Science, 5, 31 (2019) 